\title{
TEKNOLOGI PETERNAKAN TERPADU BERBASIS ENERGI BARU TERBARUKAN DI KABUPATEN TANGERANG
}

\author{
Rosiana Indrawati ${ }^{1, *}$, Sri Haryanti Prasetiyowati ${ }^{2}$, Primanda Kiky Widyaputra ${ }^{3}$ \\ ${ }^{1}$ Program Studi Teknik Energi Fakultas Teknologi Industri \\ ${ }^{2,3}$ Program Studi Teknik Kelautan Fakultas Sumberdaya Alam \\ Institut Teknologi Yogyakarta \\ Jalan Janti km 4 Gedongkuning Yogyakarta \\ Email Korespondensi : *Rosiana.Indrawati@gmail.com
}

Received : November 29, 2020 ; Accepted : December 22 , 2020 ; Published : January $1^{\text {st }}, 2021$

\begin{abstract}
Abstrak
Kabupaten Tangerang memiliki peternakan sapi terbesar di Provinsi Banten. Kegiatan usaha peternakan dapat menimbulkan dampak positif yaitu meningkatkan kegiatan ekonomi masyarakat, juga menimbulkan dampak negatif lingkungan yaitu limbah peternakan baik limbah padat maupun cair. Mitra dalam kegiatan ini adalah kelompok usaha peternakan Agro Arafahdan UMKM Barokah berlokasi di Desa Pakulonan Barat Kecamatan Kelapa Dua Kabupaten Tangerang. Selama ini pengelolaan limbah peternakan hanya sebatas dikumpulkan kemudian dimanfaatkan untuk pupuk tanaman. Teknologi yang akan diimplementasikan adalah reactor biogas kapasitas $12 \mathrm{~m} 3$, mesin pencacah, mesin pengaduk pakan, pompa air bertenaga surya dan tandon air 500 liter, dan PLTS berkapasitas $300 \mathrm{WP}$. Tahapan kegiatannya dimulai dari mengindentifikasi kondisi rill mitra terkait penerapan teknologi, merancang dan membuat sistem teknologi, pengujian terhadap sistem teknologi yang telah dibuat, serta melakukan pelatihan dan pendampingan kepada mitra dalam mengoperasikan dan memanfaatkan teknologi yang telah didiseminasikan. Output kegiatan ini adalah pemanfaatan biogaskotoran sapi untuk memasak dan lampu penerangan kandang, terpasangnya pompa air bertenaga surya untuk menyedot air dari sumur ke dalam tandon , yang nantinya bisa dimanfaatkan untuk keperluan minum dan memandikan sapi maupun operasional kandang lainnya, mesin pencacah rumput dan pengaduk pakan dapat membantu menyediakan pakan sapi yang bermutu tinggi sehingga meningkatkan produktifitas sapi sampai $50 \%$.
\end{abstract}

Kata kunci: Peternakan Sapi, Biogas,PLTS, Kabupaten Tangerang.

\begin{abstract}
Tangerang Regency has the largest cattle farm in Banten Province. Animal husbandry business activities can have a positive impact, namely increasing community economic activities, as well as negative environmental impacts, namely livestock waste both solid and liquid waste. Partners in this activity are the Arafah Agro livestock business group and Barokah UMKM located in Pakulonan Barat Village, Kelapa Dua District, Tangerang Regency. So far, livestock waste management is only limited to being collected and then used for plant fertilizer. The technology to be implemented is a biogas reactor with a capacity of $12 \mathrm{m3}$, a chopper, a feed mixer, a solar powered water pump and a 500 liter water reservoir, and a PLTS with a capacity of $300 \mathrm{WP}$. The stages of its activities start from identifying the real conditions of partners related to the application of technology, designing and making technology systems, testing the technology systems that have been made, and conducting training and mentoring to partners in operating and utilizing technology that has been
\end{abstract}


disseminated. The output of this activity is the use of cow biogascoture for cooking and lighting for cages, the installation of a solar powered water pump to suck water from the well into the reservoir, which can later be used for drinking and bathing cows and other stable operations, grass chopper and feed mixer. help provide high quality cow feed, thereby increasing cow productivity by up to $50 \%$.

Keywords: Cattle Farming, Biogas, Solar Home System, Tangerang Regency

\section{Pendahuluan}

Peternakan menjadi salah satu bidang prioritas dalam program Kementerian Perencanaan Pembangunan Nasional tentang aksi mitigasi bidang pertanian yang dilaksanakan di tingkat nasional, provinsi dan kabupaten/kota. Program tersebut selaras dengan program Kementerian Pertanian yang berupaya mewujudkan swasembada daging melalui peningkatan populasi ternak. Berdasarkan data BPS Tangerang (2013) kecamatan yang memiliki populasi lebih dari 2.000 ekor sapi yaitu Teluknaga (15.657 ekor), Legok (7.115 ekor), Jambe (2.563 ekor) dan Panongan (2.085 ekor). Tingginya populasi sapi potong di 5 kecamatan tersebut tak lain karena adanya perusahaan swasta yang bergerak dibidang penggemukan (feedloter). Sedangkan kisaran populasi di 10 kecamatan lainnya sekitar 113 ekor - 1.204 ekor dengan rata-rata per kecamatan 521 ekor.

Salah satu peternakan yang dikembangkan di Provinsi Banten adalah peternakan AGRO ARAFAH yang terletak di Kelurahan Pakulonan Barat Kecamatan Kelapa Dua Kabupaten Tangerang. Peternakan ini memiliki populasi sapi sebanyak +50 ekor yang dikelola oleh kelompok tani ternak yang diketuai oleh Bu Nila Utami. Kelompok yang berdiri sejak 10 Maret 2020 ini memiliki anggota sebanyak 13 orang yang masing-masing memelihara 3-5 ekor sapi yang dipelihara di kandang komunal milik kelompok ternak tersebut. Sejak pertama berdiri, kelompok Agro Arafah sudah ingin mengelola kotoran ternaknya menjadi biogas, namun kesulitan dalam hal penguasaan teknologi dan pengadaannya karena membutuhkan biaya yang besar. Oleh karena itu, selama ini kotoran sapi hanya diolah menjadi pupuk kandang saja yang dimanfaatkan oleh anggota kelompok tersebut maupun masyarakat sekitar.

Di sisi lain, penyediaan pakan yang berkualitas juga sangat mutlak diperlukan dalam pembesaran sapi [1]. Selama ini, sapi yang dipelihara oleh kelompok Agro Arafah hanya diberi makan hijauan rumput dalam bentuk utuh tanpa proses pengolahan sama sekali, sehingga kurang bisa dicerna dengan baik. Selain itu, penambahan nutrisi makanan tambahan seperti protein dan zat-zat lainnya masih sangat kurang, karena terbatasnya dana untuk membeli nutrisi tersebut. Selama ini kebutuhan suplemen makanan tambahan sapi tersebut didapatkan kelompok ternak Agro Arafah dari UMKM Barokah, yang mendapatkan suplemen-suplemen tersebut dari produsennya langsung. Padahal, jika mereka bisa membuat bahan tambahan makanan sapi tersebut, akan bisa meningkatkan produktifitas sapi mereka dengan harga yang terjangkau. Tentunya pembuatan makanan tambahan sendiri tersebut membutuhakn teknologi yang efektif dan efisien, seperti mesin pengaduk bahan makanan agar tercampur merata. Sehingga diperlukan teknologi peternakan terpadu untuk dapat mengelola kegiatan peternakan di Agro Arafah [4].

\section{Metode}

Untuk mencapai target luaran yang direncanakan, metode pelaksanaan program yang akan diterapkan adalah sebagai berikut:

A. Penerapan teknologi pengembangan Teknologi Peternakan Terpadu berbasis Energi Baru Terbarukan

a) Sistem penerapan Teknologi Peternakan Terpadu berbasis Energi Baru Terbarukan adalah serangkaian proses pengembangan teknologi mulai dari 
mengindentifikasi kondisi mitra, perancangan dan pembuatan mesin, pengujian operasional mesin sampai dengan pendampingan dan pelatihan operasional teknologi tersebut [7].

b) Hal-hal yang sudah dilakukan antara lain :.

1) Identifikasi kondisi mitra terkini.

Kegiatan ini dilakukan untuk mengidentifikasi kebutuhan pelaksanaan program ini, mulai dari lokasi pembangunan instalasi biogas, penempatan mesin pencacah hijauan rumput dan pengaduk pakan, penempatan pompa dan tandon air, serta lokasi penempatan pembangkit listrik tenaga surya.

2) Perancangan dan Pembuatan teknologi

Setelah mendapatkan detail informasi mengenai kondisi mitra terkini, akan dilanjutkan dengan pembangunan instalasi biogas di lapangan oleh tenaga-tenaga yang handal dan berpengalaman dalam membangaun instalasi biogas dan pemasangan PLTS.

Adapun teknologi-teknologi yang akan diterapkan adalah sebagai berikut:

1. Reaktor Biogas Fiber

a. Fungsi : Tempat terjadinya konversi kotoran sapi menjadi biogas sebagai bahan bakar alternatif pengganti LPG [10].

b. Spesifikasi teknologi :

1)

2)

3)

4) Asessoris $20 \mathrm{~m}$, manometer

5)

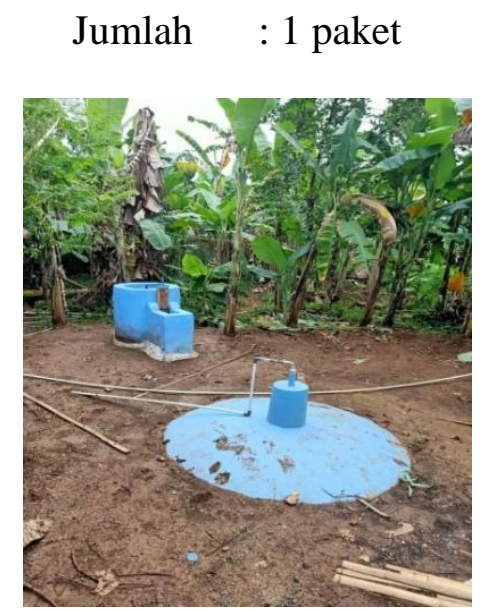

Gambar 1. Reaktor Biogas tipe fixed-dome

Jumlah : 1 paket
Dimensi reaktor : diameter $280 \mathrm{x}$ tinggi $200 \mathrm{~cm}$

Kapasitas : $12 \mathrm{~m}^{3}$

Jumlah ternak : 11-12 ekor sapi

: kompor, tungku, pipa PVC 0,5 inch, saluran biogas

2. Mesin Pencacah Hijauan Rumput Tenaga Surya

a. Fungsi : Mencacah bahan organik untuk pakan ternak (rumput, daun jagung, batang pisang, enceng gondok, dll) menggunakan sumber energi matahari[2].

b. Spesifikasi teknologi :
1) Dimensi
2) Kapasitas
: $600 \times 400 \times 700 \mathrm{~mm}$
3) Penggerak
: $50 \mathrm{~kg} / \mathrm{jam}$
4) Bahan
: motor listrik 0,5 PK (372,5 watt)
5) Jumlah pisau
: Mild steel
6) Jumlah
: 2 blade
: 1 paket 


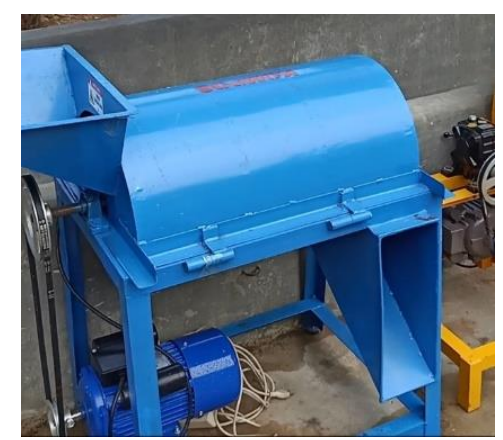

Gambar 2. Mesin pencacah rumput bertenaga surya

3. Mesin Pengaduk Pakan Tenaga Surya

a. Fungsi : Mencampur bahan pakan agar homogen, menggunakan sumber energi matahari [6].

b. Spesifikasi teknologi :
1) Kapasitas
: $150 \mathrm{~kg} / \mathrm{jam}$
2) Penggerak : motor listrik 0,5 PK (372,5 watt)
3) Bahan
: Mild Steel
4) Rangka siku
: $40 \mathrm{~mm}$
5) Jumlah
: 1 paket

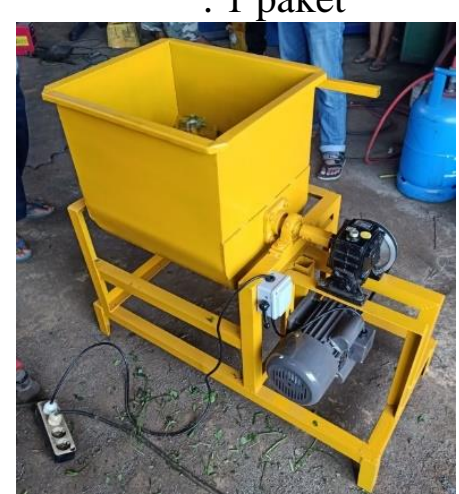

Gambar 3. Mesin pengaduk pakan bertenaga surya

4. Pompa Air Tenaga Surya

a. Fungsi : Memompa air dari sumur ke dalam tandon/langsung ke kandang, menggunakan sumber energi dari tenaga surya.

b. Spesifikasi teknologi :
1) Tipe pompa
: Semijet
2) Kapasitas pompa
: 55 liter/menit
3) Kebutuhan listrik
: 100 watt
4) Kemampuan dorong
5) Jumlah
: 16 - 22 meter
: 1 unit 


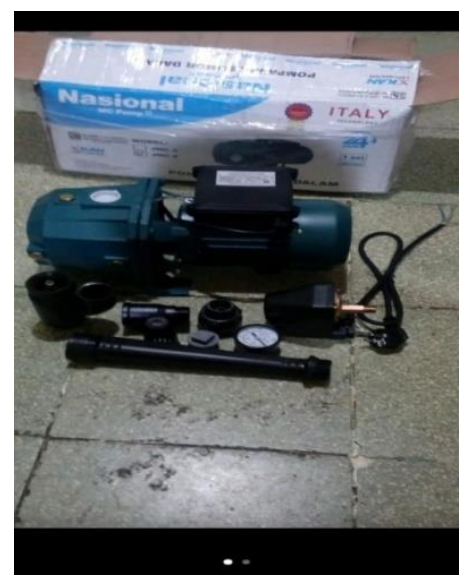

Gambar 4. Pompa Air Tenaga Surya

5. Tandon Air

a. Fungsi : Menampung air yang dipompa dari sumur untuk kebutuhan minum maupun membersihkan kandang sapi.

b. Spesifikasi teknologi :
1) Dimensi
: $830 \times 1100 \mathrm{~mm}$
2) Kapasitas
: 550 liter
3) Bahan
: HDPE
4) Diameter tutup
: $400 \mathrm{~mm}$
5) Jumlah
: 2 unit

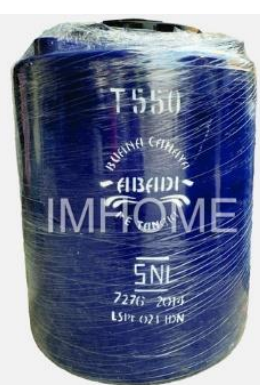

Gambar 5. Tandon air

6. Pembangkit Listrik Tenaga Surya (Solar Home System)

a. Fungsi : Menyediakan sumber energi listrik bertenaga matahari untuk kebutuhan mesin pencacah, mesin pengaduk \& pompa air serta penerangan sehari-hari [8]

b. Spesifikasi teknologi :

\begin{tabular}{l|l|c}
\multicolumn{3}{c}{ Tabel 1.Spesifikasi Teknik PLTS } \\
\hline \multicolumn{1}{c}{ Komponen } & \multicolumn{1}{|c}{ Keterangan } & QTY \\
\hline PV Modul & Solar panel 300 Wp & 1 Pcs \\
\hline Baterai & 12 V - 100 Ah MF / GEL & 1 Pcs \\
\hline Solar Charger Controller & Solar Charge 12 V / 20 A & 1 Pcs \\
\hline Inverter (Optional) & DC to AC 1000 Watt & 1 Pcs \\
\hline Lampu & Lamp LED 3 W & 1 Pcs \\
\hline Aksesoris & 1) Box Baterai & 1 Set \\
& 2) PV Module Support & \\
& 3) Tiang Penyangga (HDG) & \\
\hline
\end{tabular}




\begin{tabular}{l|l|l}
\hline & 4) Kabel Instalasi (10 m) & \\
& 5) Kabel PV Modul (7 m) & \\
& 6) Saklar (1 set) & \\
7) Material Instalasi (1 set) & \\
\hline
\end{tabular}

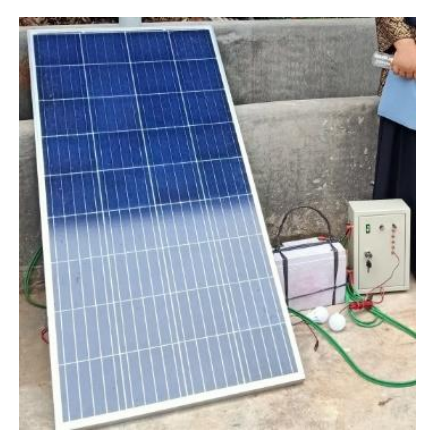

Gambar 6. Satu Paket Pembangkit Listrik Tenaga Surya (SHS)

\section{B. Pengujian Operasional Teknologi}

Setelah pemasangan instalasi dan pembuatan mesin-mesin tersbeut selesai, dilakukan pengujian terhadap operasional instalasi biogas dan PLTS serta mesin pencacah hijauan rumput dan pengaduk pakan tersebut. Tahapan pengujian ini dilakukan untuk melihat kehandalan dari teknologi-teknologi yang telah dibuat.

\section{Hasil Dan Pembahasan}

Kegiatan Pengabdian Masyarakat melalui Program Produk Teknologi yang di Desiminasikan Kepada Masyarakat ini dilakukan dalam 3 tahap.

a. Tahap Pertama, observasi kondisi permasalahan mitra yaitu Kelompok Tani Ternak Agro Arafah pimpinan Ibu Nila Utami dan UMKM Barokah sebagai penyedia pakan untuk ternak sapi. Permasalahan yang paling utama bagi mitra Agro Arafah adalah pengelolaan kotoran sapi yang jumlahnya cukup besar setiap harinya, yang kedua adalah ketergantungan pada listrik dari PLN yang membebani untuk operasional setiap bulannya.

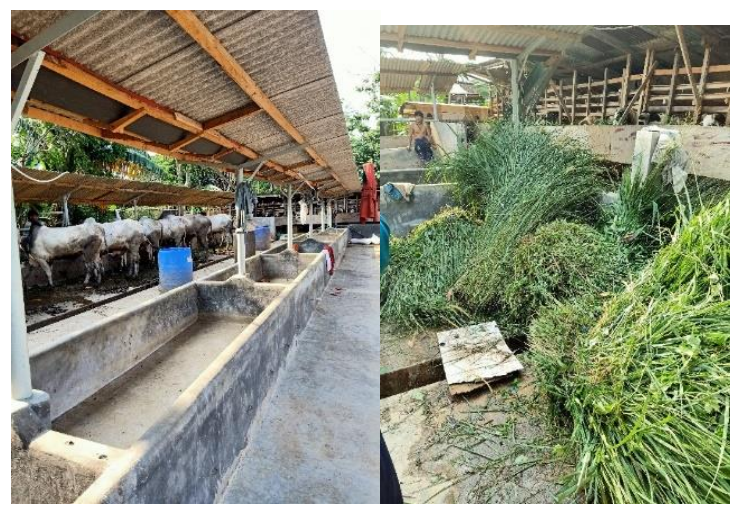

Gambar 7. Suasana di Lokasi Mitra

b. Tahap Kedua, Pembuatan Alat dan Uji Coba Alat.

Tahap Kedua tim pengusul mendesain teknologi yang dapat mengatasi permasalahan mitra melalui kegiatan Pembuatan biogas reaktor kapasitas $12 \mathrm{~m} 3$ dengan konstruksi beton, mesin-mesin pencacah rumput kapasitas $50 \mathrm{~kg} / \mathrm{jam}$ dan mesin pengaduk pakan kapasitas $150 \mathrm{~kg} / \mathrm{jam}$, pompa air semijet tenaga surya, bak penampung air 500 liter, PLTS kapasitas 300 WP. Pembangunan konstruksi reaktor biogas telah dilakukan pada pertengahan Oktober dan telah dilakukan uji coba selama 10 hari. Hasilnya 
beradasrkan pengukuran yang dilakukan oleh tim teknis, volume biogas pada hari ke 10 mencapai $28 \mathrm{~m} 3$ dan hal tersebut belum mencapai kondisi maksimal artinya gas masih akan terus berproduksi. Diasumsikan 1 ekor sapi dapat menghasilkan $10 \mathrm{~kg}$ kotoran sapi per hari. Sehingga jika jumlah ternak ada 12, maka jumlah kotoran sapi yang dihasilkan $=120 \mathrm{~kg} /$ hari. Jumlah tersebut dapat menggunakan reactor biogas dengan kapasitas 8-12 m3 dan jumlah kalori yang dihasilkan adalah 41600-47200 Kcal [5].

Biogas yang dihasilkan telah dimanfaatkan oleh petani ternak dan juga karyawannya untuk memasak sehari-hari di lokasi peternakan. Hal tersebut dapat menghemat biaya pembelian gas elpiji yang setiap bulannya mereka membutuhkan 2 tabung elpiji $3 \mathrm{~kg}$ untuk keperluan memasak. Reaktor biogas $12 \mathrm{~m} 3$ dapat menghasilkan gas bio sebesar 4,2- 4,8 m3 [3]. Sedangkan $1 \mathrm{~m} 3$ biogas setara dengan 0,46 kg elpiji. Sehingga besarnya volume biogas dalam sehari dapat disetarakan dengan $9 \mathrm{~kg}$ gas elpiji.

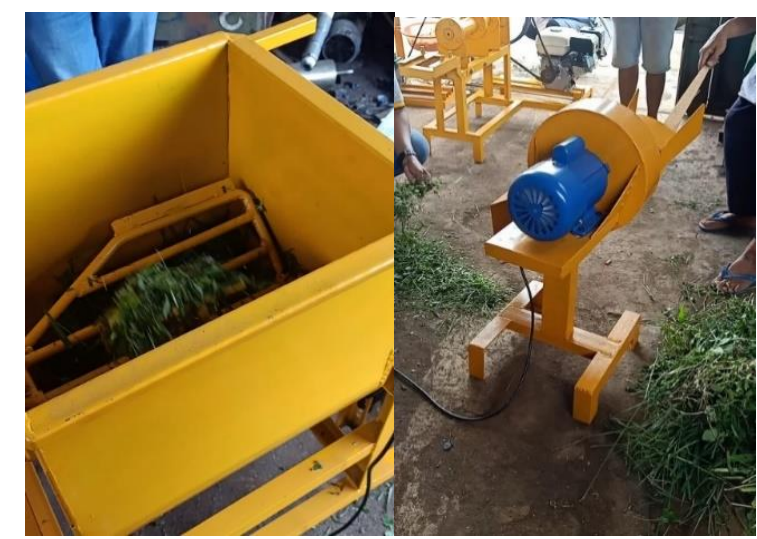

Gambar 8. Uji Coba Mesin Pencacah Rumput dan Pengaduk Pakan

c. Tahap Ketiga, Sosialisasi dan Serah Terima Teknologi

Kegiatan sosialisasi dilakukan pada tanggal 10 November 2020 pukul 15.00 WIB bertempat di Kelompok Tani Ternak Agro Arafah Kelurahan Pakulonan Barat Kecamatan Kelapa Dua Kabupaten Tangerang. Dalam kegiatan sosialisasi ini dihadiri lebih dari 20 anggota kelompok tani ternak, perangkat kelurahan, Dinas terkait (BPPT, LIPI dan Dinas Peternakan dan Pertanian Kabupaten Tangerang). Dalam acara sosialisasi dan serah terima teknologi ini juga dihadiri oleh perwakilan dari DPR RI komisi VII yaitu Bapak Zulfikar Hamongangan, S.H. dalam sambutannya selaku narasumber, beliau menyampaikan terimakasih kepada Kemenristek BRIN dan Institut Teknologi Yogyakarta melalui tim pengusul atas hibah teknologi yang telah diberikan krepada mitra untuk memajukan peternakan di Kabupaten Tangerang.

Respon mitra terhadap teknologi yang didesiminasikan adalah mereka sangat berterimakasih dan teknologi tersebut dapat membantu mereka menghemat pengeluaran biaya operasional listrik bulanan sekaligus menghemat dalam pembelian gas elpiji $3 \mathrm{~kg}$. Dalam satu bulan mereka mengkonsumsi 2 tabung elpiji kapasitas $3 \mathrm{~kg}$ untuk memasak sehingga harus mengeluarkan biaya Rp.40.000/bulan. dan untuk pengembangannya nantinya sisa gas dapat dimanfaatkan untuk menghidupkan mesin genset. 


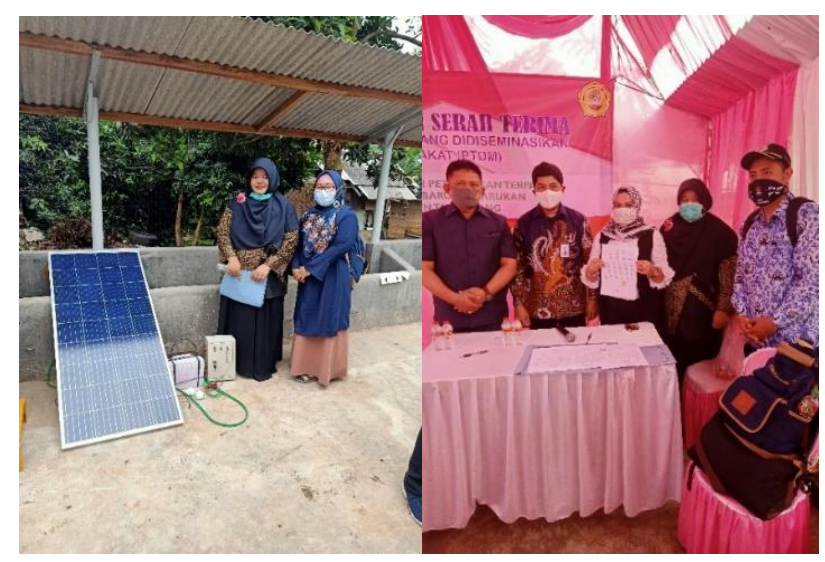

Gambar 9. Uji Coba PLTS 300 WP dan Serah Terima Teknologi

Begitupula dengan penggunaan panel surya 300 wp. Dalam kondisi sinar matahari bersinar penuh selama 4 jam, panel tersebut dapat menghasilkan listrik 300/4 = 75 watt. Baterei $100 \mathrm{Ah}, 12 \mathrm{~V}$ yang artinya dapat menyimpan 100x12 = $120 \mathrm{watt} / \mathrm{jam}$ [9]. Sehingga penggunaan teknologi PLTS dapat menghemat biaya operasional untuk pembayaran rekening listrik karena dapat disuplai dari listrik PLTS $300 \mathrm{wp}$ untuk lampu penerangan dan pompa air semijet. Sehingga mereka dapat menghemat biaya listrik $50 \%$ atau sekitar Rp.150.000,- dari pengeluaran bulanan yaitu Rp.300.000,-

Selain itu, penggunaan mesin pencacah rumput dan pengaduk pakan telah dapat meningkatkan produktivitas sapi terbukti dari penambahan jumlah sapi yaitu sekitar 16 ekor. Hal tersebut dikarenakan ketersediaan pakan yang cukup baik dalam kualitas maupun kuantitasnya. Selain itu juga disebabkan kondisi kandang yang terjaga kebersihannya dan ketersediaan air minum yang melimpah.

\section{Kesimpulan}

Adapun kesimpulan yang dapat diperoleh adalah Kegiatan pengabdian ini dilaksanakan dalam bentuk pemberian bantuan alat dan pelatihan pemanfaatan teknologi peternakan terpadu berbasis energi baru terbarukan dan disimpulkan berhasil, kaerena dapat terlaksana dengan baik karena semua teknologi sudah langsung dimanfaatkan.

\section{Daftar Pustaka}

[1] A.C. Adityawarman, Salundik, Lucia, "Pengolahan Limbah Ternak Sapi Secara Sederhana di Desa Pattalassang Kabupaten Sinjai Sulawesi Selatan", Jurnal Ilmu Produksi dan Teknologi Hasil Peternakan Vol. 03 No. 3 Oktober 2015.

[2] A. Hanafie, Fadhli, I. Syahruddin, Rancang Bangun Mesin Pencacah Rumput Untuk Pakan Ternak, ILTEK, Volume 11, Nomor 01, April 2016.

[3] A. Pertiwiningrum."'Instalasi Biogas". Oktober. 2016.

[4] E.T Marlina, Y.A Hidayati, D.Z. Badruzzaman, "Pengolahan Terpadu Limbah Ternak di Kelompok Tani Rancamulya Sumedang”, Media Kontak Tani Ternak, Agustus 2019, 1(1):5-10 Published by Fakultas Peternakan UNPAD

[5] Kasno Kasdin, Evaluasi Pengelolaan Limbah Peternakan Menjadi Biogas di Kelurahan Ngadirgo, Kecamatan Mijen, Kota Semarang, Prosiding Seminar Nasional Innovation in Environmental Management 2015 Diponegoro University dan Queensland University.

[6] Kurniawan, U. Lesmanah, Margianto, "Perancangan Mesin Pengaduk Pakan Ternak Sapi”, Jurnal Sains dan Teknologi Teknik Mesin Unisma, Vol 11, No 01 (2018) 
[7] N. Fitriyanto, S. Triatmojo, A. Pertiwiningrum, Y. Erwanto, MZ. Abidin, E. Baliarti, Y.Y. Suranindyah, "Penyuluhan Dan Pendampingan Pengolahan Limbah Peternakan Sapi Potong Di Kelompok Tani Ternak Sido Mulyo Dusun Pulosari, Desa Jumoyo, Kecamatan Salam, Kabupaten Magelang “, Indonesian Journal of Community Engagement Vol. 01, No. 01, September 2015

[8] S. N. Rumokoy and C. H. Simanjuntak, "Perancangan Konsep Modul Praktek Instalasi PLTS Skala Rumah Tangga Berbasis Kompetensi Berorientasi Produksi," Fokus Elektroda, vol. 04, no. 04, pp. 6-12, 2016

[9] S. Putra, J. T. Mesin, F. T. Industri, and U. Trisakti, "Perencanaan Pembangkit Listrik Tenaga Surya Secara Mandiri Untuk Rumah Tinggal," pp. 1-7, 2016.

[10] Y. Sulistiyanto, Sustiyah, S. Zubaidah, B. Satata, "Pemanfaatan Kotoran Sapi Sebagai Sumber Biogas Rumah Tangga Di Kabupaten Pulang Pisau Provinsi Kalimantan Tengah", Jurnal Udayana Mengabdi, Volume 15 Nomor 2, Mei 2016. 
Rosiana Indrawati, Sri Haryanti Prasetiyowati, Primanda Kiky Widyaputra 